\title{
HETEROSIS AND ADDITIVE GENETIC EFFECTS FOR BODY WEIGHT IN UPGRADING BURUNDI ANKOLE CATTLE WITH SAHIWAL
}

\author{
M.R. Anous ${ }^{1}{ }^{*}$, G.F. Gouda ${ }^{1}$ and H. Nimenya ${ }^{2}$ \\ 1 Department of Animal Production, Faculty of Agriculture, Ain Shams University, P.O. Box 68 Hadayek Shoubra, \\ 11241 Cairo, Egypt, 2 Institut Supérieur d'Agriculture (ISA), B.P. 35, Gitega, Burundi
}

\section{SUMMARY}

Data on 139 bull calves and 174 heifer calves, representing the Ankole and Sahiwal purebred cattle and their crosses, were used to evaluate the effect of grading up Ankole cattle of Burundi with Sahiwal cattle of Pakistan on live body weights of calves at birth, weaning, 1 year, 2 years and 3 years of age. Two statistical models were used for analyzing the data; the first included the main effects of genetic group, farm (i.e. station) and sex, and the second was used to estimate total heterosis and additive genetic effects for live body weights. The effect of genetic group and sex were highly significant for all weights considered, however, effect of farm (i.e. station) was only significant $(P<$ $0.001)$ for both weaning weight and live body weight at 12 months of age. The additive genetic effect was relatively more important than the total heterosis effect for live weights of weaning, 24 and 36 months of age. The effect of total heterosis was significant for weights at birth, weaning and 24 months of age and not significant $(P>0.05)$ for weights at 12 and 36 months of age. The additive genetic effect was not significant $(P>0.05)$ for both birth weight and weight at 12 months of age in contrary with the other weights.

Keywords: Ankole and Sahiwal cattle, body weights, heterosis, additive genetic

\section{INTRODUCTION}

Although heterosis is often believed to be most pronounced for reproductive traits, it is also manifested in characters such as growth rate, carcass traits and feed consumption (Gregory et al., 1965 and 1966a,b; Preston and Willis, 1970; Sacker et al., 1971; Cundiff et al., 1974a,b; Long and Gregory, 1974 and 1975; Trail et al., 1982; Baik and Kim, 1986 and Fordyce et al., 1993). Systematic crossbreeding provides for use of heterosis and of differences among breeds to optimize average genetic merit of traits for adaptability to the various climatic and nutritive environments encountered in beef production (Dickerson, 1973; Gregory and Cundiff, 1980 and Koch et al., 1985). Heterosis achieved through continuous crossbreeding can also be used to increase live and carcass performance traits in cattle (Gregory and Cundiff, 1980; Cundiff and Gregory, 1999; Osorio and Segura, 2010; Lauren, 2014 and Williams et al., 2014). The factor that could be responsible for continued improvement when grading is practiced (one of the methods of crossbreeding), introducing the desirable additive genes with plus effects into a herd that originally lacked them (Lasley, 1978).

In Burundi, the Ankole cattle constitute the major part of cattle population. It is known by its low productivity. A program of up-grading for this breed with the imported Sahiwal cattle, native to the Punjab province of Pakistan, was established in 1978 by the Agriculture Sciences Institute of Burundi (i.e. Institut des Sciences Agronomiques du Burundi; ISABU) for improving milk and meat production in these upgrades.
Generally, the Sahiwal is one of the best Bos indicus breeds with genetic potential for milk and beef, while exhibiting a complete adaptation to the tropics. The moderate purebred and crossbred performance of the Sahiwal breed has been reported in some tropical production systems and environments (Trail and Gregory, 1981). In an attempt to evaluate this trail of crossing Ankole-Sahiwal, two studies were carried out. The first study was concerned with the evaluation of milk production performance of the Ankole-Sahiwal crossbred cows (Anous et al., 2000). The second (i.e. the present study) deals with the genetic evaluation of live body weights of the crossbred calves through upgrading Ankole cattle of Burundi with Sahiwal cattle of Pakistan. Therefore, the aim of the current study is to estimate total heterosis and additive genetic effects for live body weights of calves of both sexes.

\section{MATERIAL AND METHODS}

\section{Animals and management}

A crossbreeding program started in 1978 at all Research Stations of Agriculture Sciences, Institute of Burundi (i.e. Institut des Sciences Agronomiques du Burundi; ISABU) by up-grading Ankole cows (ANK) of Burundi with the semen of the imported Sahiwal sires (S) up to $15 / 16 \mathrm{~S}$. A total of 313 calves, including 139 bull calves and 174 heifer calves produced by artificial insemination mating (AI), were available for the present study. Data were collected during the period from 1991 to 1995. Calves were from two experimental 
farms; RUKOKO (Farm I), situated in the natural region of the IMBO (north-west of the country), and MAHWA (Farm II), situated in the central plateau of the BUTUTSI region (centre of the country). The animals were grouped according to the proportion of Sahiwal breed (S) in six genetic groups: Pure Ankole (A), 1/2 Sahiwal, 3/4 Sahiwal, 7/8 Sahiwal or $87.5 \% \mathrm{~S}$, $15 / 16$ Sahiwal or $93.75 \%$ S and Pure Sahiwal or $100 \%$ $\mathrm{S}$. The latter genetic group was produced by AI of the progeny of imported pure Sahiwal cows with the semen of the imported S sires. Data in Table (1) summarize the distribution of animals by farm (i.e. station), genetic group and sex. At the research stations, the animals were grazed on natural pastures from November to mid June (during the rainy season), whereas during the dry season they were fed ad libidum, beside grass, on legume silage. Calving season starts in late January. At calving, each calf was individually weighed (i.e. birth weight, BW) and identified using ear tags. Calves suckled their dams until weaning at 7 months of age and weaning weight was recorded (WW). Weights at 12,24 , and 36 months of age were also recorded $(12 \mathrm{~W}$, $24 \mathrm{~W}$ and $36 \mathrm{~W}$, respectively).

\section{Statistical analysis}

Data of live body weights were analyzed using two different linear models. GLM procedure (SAS, 2001) was used to study the effect of sex, farm and genetic group on live body weights from birth to 36 months of age according to the following model:

$\mathrm{Y}_{\mathrm{ijkl}}=\mu+\mathrm{S}_{\mathrm{i}}+\mathrm{F}_{\mathrm{j}}+\mathrm{G}_{\mathrm{k}}+(\mathrm{SF})_{\mathrm{ij}}+\mathrm{e}_{\mathrm{ijkl}}$

\section{Model 1}

Where:

$\mathrm{Y}_{\mathrm{ijkl}}$ is the body weight of the $\mathrm{l}^{\text {th }}$ individual;

$\mu$ is the overall mean;

$S_{i}$ is the fixed effect of the $i^{\text {th }} \operatorname{sex}(i=1,2)$;
$F_{j}$ is fixed effect of the $j^{\text {th }}$ farm $(j=1,2)$;

$\mathrm{G}_{\mathrm{k}}$ is the fixed effect of the $\mathrm{k}^{\text {th }}$ genetic group $(\mathrm{k}=1, \ldots$, $6)$;

$(\mathrm{SF})_{\mathrm{ij}}$ is the interaction effect between sex and farm; $\mathrm{e}_{\mathrm{ijk}}$ is the random residual error for the $\mathrm{l}^{\text {th }}$ individual.

Interaction effects between sex and genetic group, between farm and genetic group and among sex, farm and genetic group were not statistically significant $(\mathrm{P}>$ 0.01 ), and thus they were not considered in the model. Differences among means were tested using Duncan's Multiple Range Test.

Estimates of total heterosis (included average, general and specific heterosis) and additive genetic effects for live body weights of calves were calculated (Fimland, 1983) according to the following model:

$\mathrm{Y}_{\mathrm{ijbcf}}=\mu+\mathrm{S}_{\mathrm{i}}+\mathrm{F}_{\mathrm{j}}+(\mathrm{SF})_{\mathrm{ij}}+\sum \mathrm{k}_{\mathrm{b}} \mathrm{a}_{\mathrm{b}}+\sum \mathrm{k}_{\mathrm{bc}} \mathrm{h}_{\mathrm{bc}}+\mathrm{e}_{\mathrm{ijbcf}}$

\section{Model 2}

Where:

$Y_{\mathrm{ijbcf}}$ is the body weight of the $f^{\text {th }}$ individual;

$\mu$ is the overall mean;

$S_{\mathrm{i}}$ is the fixed effect of the $i^{\text {th }} \operatorname{sex}(\mathrm{i}=1,2)$;

$F_{\mathrm{j}}$ is fixed effect of the $\mathrm{j}^{\mathrm{t}}$ farm $(\mathrm{j}=1,2)$;

$(S F)_{\mathrm{ij}}$ is the interaction effect between sex and farm;

$k_{b}$ is the proportion of genes contributed by the $f^{\text {th }}$ individual originating from the $\mathrm{b}^{\text {th }}$ genetic group $\left(k_{\mathrm{b}}\right.$ $=0.0,0.5$ or 1.0 and $\sum k_{b}=1.0$ );

$a_{b}$ is the additive genetic effect of genes originating from the $b^{\text {th }}$ genetic group;

$k_{\mathrm{bc}}$ is the coefficient of the total heterosis effect for the crossbred between the $b^{\text {th }}$ and the $c^{\text {th }}$ genetic groups $\left(k_{\mathrm{bc}}=0\right.$ or $1.0 ; b \neq c$ and $b c \neq c b$ and $\left.\sum k_{b c}=1.0\right)$;

$h_{\mathrm{bc}}$ is the total heterosis effect for the crossbred between the $b^{\text {th }}$ and the $c^{\text {th }}$ genetic groups $(b \neq c$ and $b c \neq c b)$; and

$e_{\mathrm{ijbcf}}$ is the random residual error for the $f^{\text {th }}$ individual.

Table 1. Distribution of calves considered in the study

\begin{tabular}{lcccccc}
\hline \multirow{2}{*}{ Genetic group } & \multicolumn{2}{c}{ Farm I } & \multicolumn{2}{c}{ Farm II } & \multicolumn{2}{c}{ Total } \\
\cline { 2 - 7 } & Males & Females & Males & Females & Males & Females \\
\hline Pure Sahiwal (S) & 11 & 21 & 5 & 6 & 27 & 16 \\
Pure Ankole (A) & -- & --- & 25 & 23 & 25 & 23 \\
1/2S1/2A & 13 & 9 & 9 & 13 & 22 & 22 \\
3/4S1/4A & 11 & 17 & 11 & 15 & 22 & 32 \\
7/8S1/8A & 15 & 23 & 12 & 15 & 27 & 32 \\
15/16S1/16A & 19 & 19 & 8 & 13 & 139 & 174 \\
Total & 69 & 89 & 70 & 85 & & \\
\hline
\end{tabular}

\section{RESULTS AND DISCUSSION}

Number of records analyzed for each trait is listed in Table 2 with the overall means. Mean square for live body weights is given in Table (3). The effect of genetic group in a crossing experiment between Ankole (A) and Sahiwal (S) cattle on live body weights of their progeny is given in Table (4). Estimates of total heterosis and additive genetic effects for live body weights of calves are presented in Table (5).

\section{Overall means and variations:}

The overall mean body weights of calves from both sexes in the present study (Table 2) were 23.69, 89.36, $160.15,259.30$ and $350.42 \mathrm{~kg}$ at birth, weaning, 12, 24 and 36 months of age, respectively. This confirmed the results of the two breeds reported in the tropics by Trail 
and Gregory (1981). The variability of body weights expressed by the values of $\mathrm{CV}$, especially for weaning weight $(\mathrm{CV} \%=29.73)$, showed the possibility of using crossbreeding to improve live body weight in this population of calves.

\section{Accountable variations:}

Mean squares from analysis of variance for live body weights of calves are shown in Table (3). These figures show that genetic group and sex of calf were highly significant sources of variation for body weights in all ages, while the effect of farm was only significant $(\mathrm{P}<0.001)$ for weaning and 12 months body weights. The interaction between sex and farm was significant $(\mathrm{P}<0.001)$ only for weights at weaning and 36 months of age. The significant differences among the genetic groups indicate considerable genetic diversity between the pure breeds and their crosses. There was general agreement between our results and the results reported previously in cattle by Preston and Willis (1970).

Ankole calves showed lighter weights than any of the other genetic groups at any age considered in the study (Table 4) with small differences among genetic groups in the case of birth weight. Sahiwal calves had the highest live body weights compared to the crossbred calves at the older ages (from 24 to 36 months of age). They also exceeded slightly the A calves $(\mathrm{P}>0.05)$ at the earlier ages of BW, WW and $12 \mathrm{~W}$ by $0.7,5.4$ and $9.0 \mathrm{~kg}$, respectively. This means that the crossbred genetic groups performed better than Ankole cattle at all ages.

Considering the crossbred genetic groups, $1 / 2 \mathrm{~S} 1 / 2 \mathrm{~A}$ and $3 / 4 \mathrm{~S} 1 / 4 \mathrm{~A}$ crossbred calves exceeded all the other crossbred calves in both birth and weaning weights by 6.29 and $29.18 \%$ for $1 / 2 \mathrm{~S} 1 / 2 \mathrm{~A}$ and 7.59 and $26.48 \%$ for $3 / 4 \mathrm{~S} 1 / 4 \mathrm{~A}$. However, $87.5 \% \mathrm{~S}$ calves showed the highest weights at 12 and 24 months of age (4.38 and $8.71 \%$, respectively above the mean performance of the two parental breeds), while the $93.75 \% \mathrm{~S}$ calves had the highest weight at 36 months of age $(9.93 \%$ above the mean performance of the two parental breeds) compared to the other crossbred calves. On the other hand, the $50 \% \mathrm{~S}$ showed a decreasing live body weight at the older ages (from 12 to 36 months of age), which reflects a less adaptability compared to the other crossbreds. Data in Table (4) also showed that the percentage of improving in live body weight of crossbred calves by up-grading method attained its maximum at weaning age (ranged from $8.61 \%$ to $29.18 \%$ ).

Generally, the increase of the percentage of Sahiwal breed blood in crosses was associated with a significant increase in body weights of the crossbred calves at 12 , 24 and 36 months of age (Table 4). This may be explained by the smaller weights of both the Pure Sahiwal and the Pure Ankole calves at birth and also at weaning (23.4 and $22.7 \mathrm{~kg}$ for birth weight and 80.5 and $75.1 \mathrm{~kg}$ for weaning weight, respectively) compared to the corresponding weights of the crossbred calves. It may be also due to the very low milk yield of the pure Ankole cows compared to those of the pure Sahiwal ones (Anous et al., 2000) under the Burundi condition $(593.4 \mathrm{~kg}$ vs. $2135.7 \mathrm{~kg})$, which affects the growth of the crossbred calves from birth to weaning. Cundiff et al. (1974b) reported Angus x Hereford-cross females to be superior to Hereford $\mathrm{x}$ Angus-cross females in maternal ability as reflected by calf weaning weight. These results mean that the effect of heterosis for improving live body weights of calves in the Ankole-Sahiwal crosses is more important at the older ages compared to the younger ones; started at the age of 12 months and continued till the age of 36 months.

\section{Crossbreeding components}

The relative importance of the heterosis and additive genetic effects for live body weights of calves are shown in Table (5). The contribution of these effects within and across the five live body weights considered assumed to be different. The additive genetic effect (Sahiwal breed as deviation from Ankole breed) was relatively more important than the total heterosis effect for the crossbred between the two genetic groups (Ankole and Sahiwal cattle breeds.

Table 2. Number of animals (N), overall means $(\mathrm{kg})$, standard deviations (SD) and coefficients of variation (CV\%) for live body weight traits of calves

\begin{tabular}{lcccc}
\hline Body weight & N & Mean \pm SE & SD & CV\% \\
\hline Birth weight (BW) & 313 & $23.69 \pm 0.19$ & 3.42 & 14.44 \\
Weaning weight $(\mathrm{WW})$ & 309 & $89.36 \pm 1.51$ & 26.57 & 29.73 \\
12 month weight $(12 \mathrm{~W})$ & 309 & $160.15 \pm 1.72$ & 30.15 & 18.83 \\
24 month weight $(24 \mathrm{~W})$ & 307 & $259.30 \pm 2.53$ & 44.36 & 17.11 \\
36 month weight $(36 \mathrm{~W})$ & 297 & $350.42 \pm 2.73$ & 47.12 & 13.45 \\
\hline
\end{tabular}


Table 3. Mean squares of analysis of variance for the effect of genetic group, sex and farm on live body weights of calves

\begin{tabular}{lccccc}
\hline & \multicolumn{4}{c}{ Live body weights $\dagger$} \\
\cline { 2 - 5 } Effect & BW & WW & $12 \mathrm{~W}$ & $24 \mathrm{~W}$ & $36 \mathrm{~W}$ \\
\hline Genetic group & $31.1 *$ & $8316^{* * *}$ & $3692 * * *$ & $26829 * * *$ & $45117 * * *$ \\
Sex & $247 * *$ & $15085^{* * *}$ & $17404 * * *$ & $30161 * * *$ & $34115 * * *$ \\
Farm & 12.1 & $32543 * * *$ & $18071 * * *$ & 2581 & 616 \\
Sex x Farm & 28 & $4440 * * *$ & 140 & 368 & $22112 * * *$ \\
\hline
\end{tabular}

$\dagger: \mathrm{BW}=$ Birth weight, $\mathrm{WW}=$ Weaning weight, $12 \mathrm{~W}=12$ month weight, $24 \mathrm{~W}=24$ month weight; $36 \mathrm{~W}=36$ month weight; $*=\mathrm{P}<$ $0.05, * *=\mathrm{P}<0.01, * * *=\mathrm{P}<0.001$.

Table 4. Means of live body weights of calves in different genetic groups ${ }^{\mathrm{T}}$

\begin{tabular}{lccccc}
\hline Genetic group & $\begin{array}{c}\text { Birth } \\
\text { weight }\end{array}$ & $\begin{array}{c}\text { Weaning } \\
\text { weight }\end{array}$ & $\begin{array}{c}\text { 12 month } \\
\text { weight }\end{array}$ & $\begin{array}{c}\text { 24 month } \\
\text { weight }\end{array}$ & $\begin{array}{c}\text { 36 month } \\
\text { weight }\end{array}$ \\
\hline Pure Sahiwal (S) & $23.4^{\mathrm{BC}} \pm 0.51$ & $80.5^{\mathrm{BC}} \pm 3.42$ & $164.4^{\mathrm{AB}} \pm 4.40$ & $279.5^{\mathrm{A}} \pm 6.01$ & $383.8^{\mathrm{A}} \pm 5.56$ \\
Pure Ankole (A) & $22.7^{\mathrm{C}} \pm 0.52$ & $75.1^{\mathrm{C}} \pm 3.59$ & $155.4^{\mathrm{AB}} \pm 4.60$ & $225.7^{\mathrm{B}} \pm 6.41$ & $287.9^{\mathrm{E}} \pm 6.68$ \\
$1 / 2 \mathrm{~S} 1 / 2 \mathrm{~A}$ & $24.5^{\mathrm{AB}} \pm 0.49$ & $100.5^{\mathrm{A}} \pm 3.31$ & $152.2^{\mathrm{B}} \pm 4.24$ & $228.5^{\mathrm{B}} \pm 5.8$ & $323.2^{\mathrm{D}} \pm 5.37$ \\
$3 / 4 \mathrm{~S} 1 / 4 \mathrm{~A}$ & $24.8^{\mathrm{A}} \pm 0.44$ & $98.4^{\mathrm{A}} \pm 2.99$ & $162.5^{\mathrm{AB}} \pm 3.83$ & $268.7^{\mathrm{A}} \pm 5.24$ & $351.9^{\mathrm{C}} \pm 4.85$ \\
$7 / 8 \mathrm{~S} 1 / 8 \mathrm{~A}$ & $23.1^{\mathrm{C}} \pm 0.41$ & $94.2^{\mathrm{A}} \pm 2.73$ & $166.9^{\mathrm{A}} \pm 3.51$ & $274.6^{\mathrm{A}} \pm 4.79$ & $359.4^{\mathrm{BC}} \pm 4.44$ \\
$15 / 16 \mathrm{~S} 1 / 16 \mathrm{~A}$ & $23.7^{\mathrm{ABC}} \pm 0.43$ & $84.5^{\mathrm{B}} \pm 2.88$ & $156.9^{\mathrm{AB}} \pm 3.70$ & $266.0^{\mathrm{A}} \pm 5.06$ & $369.2^{\mathrm{B}} \pm 4.08$ \\
\hline
\end{tabular}

$\tau$ : Means in the same column with different superscripts are differ at $\mathrm{P}<0.001$.

\section{Total heterosis:}

The effect of total heterosis was significant for weights at birth $(\mathrm{P}<0.01)$, at weaning $(\mathrm{P}<0.05)$ and at 24 months of age $(\mathrm{P}<0.05)$ and were not significant (P> 0.05) for weights at 12 and 36 months of age (Table $5)$.

The results from the current study show a positive total heterosis for both birth $(3.1 \mathrm{~kg})$ and weaning $(18.1$ $\mathrm{kg}$ ) weights of calves and favored crossbred calves, however, the total heterosis was negative for weights at $12(14.9 \mathrm{~kg}), 24(31.3 \mathrm{~kg})$ and $36(1.6 \mathrm{~kg})$ months of age and favored purebred calves (Table 5). The results from the present study also show an increase in heterosis level for live body weight of calves with increasing age up to weaning and a decrease in heterosis level up to the age of 24 months, however, heterosis level for live body weight of calves at 36 months of age approached zero. A possible explanation for the decrease in level of heterosis on live body weights at older ages is that heterosis effects may be greater when environmental conditions (climatic and nutritive environment) are less favorable. Gregory et al. (1966a,b) found a higher level of heterosis in heifers than in steers when the heifers were on a lower plane of nutrition than the steers. These results support the hypothesis that heterosis in cattle for traits related to growth and size is due to dominance effects of genes Gregory et al. (1991).

\section{Additive genetic effect:}

Live body weights of animals showed higher values for the progeny in favor of Sahiwal breed for most of the traits analyzed (Table 5). The additive genetic effect was not significant $(\mathrm{P}>0.05)$ for both birth weight and body weight of animals at 12 months of age.

Table 5. Total heterosis (kg) and additive genetic effects (kg) for live body weights of calves in an upgrading of Ankole cattle with Sahiwal

\begin{tabular}{|c|c|c|c|c|c|}
\hline Contrast & $\begin{array}{c}\text { Birth } \\
\text { weight }\end{array}$ & $\begin{array}{c}\text { Weaning } \\
\text { weight }\end{array}$ & $\begin{array}{c}12 \text { month } \\
\text { weight }\end{array}$ & $\begin{array}{c}24 \text { month } \\
\text { weight }\end{array}$ & $\begin{array}{c}36 \text { month } \\
\text { weight }\end{array}$ \\
\hline Total Heterosis & $3.1 \pm 1.1 * *$ & $18.1 \pm 7.2^{*}$ & $-14.9 \pm 9.3$ & $-31.3 \pm 12.9 *$ & $-1.6 \pm 11.9$ \\
\hline $\begin{array}{l}\text { Additive genetic } \\
\text { (S-A) }\end{array}$ & $0.8 \pm 0.6$ & $25.4 \pm 4.4 * *$ & $19.9 \pm 3.4$ & $58.9 \pm 7.9 * *$ & $96.7 \pm 7.9 * *$ \\
\hline
\end{tabular}

Generally, it could be concluded that the effect of crossing for improving live body weight of calves in the
Ankole-Sahiwal crosses is more important at the older ages compared to the younger ones. The ranking of 
crosses varied from one age to another according to their weight. This confirmed by the results of the additive genetic effect in the present study (i.e. the additive genetic effect was relatively more important than the total heterosis effect for live weights of weaning, 24 and 36 months of age). For the Burundian Ankole breeders, the suggested optimal cross could be the $7 / 8$ Sahiwal.

\section{ACKNOWLEDGEMENTS}

Special thanks are due to Dr. Wagdy Mekawy, Associate Professor of Animal Breeding, Department of Animal Production, Faculty of Agriculture, Ain Shams University, Cairo for his support during data analysis. We thank the staff at the Research Stations of the Agriculture Sciences Institute of Burundi (i.e. Institut des Sciences Agronomiques du Burundi; ISABU) for their assistance during data collection.

\section{REFERENCES}

Anous M.R., S. Rashwan and H. Nimenya, 2000. The effect of grading up Ankole cattle of Burundi with Sahiwal on milk production performance of cows. Mansoura University, Journal of Agriculture Science, 25: 6077-6083.

Baik D.H. and D.C. Kim, 1986. Heterosis on body weights in crosses among Brahman, Santa Gertrudis and Cheju Native Cattle. 3rd World congress on genetics applied to livestock production. Paper 43.

Cundiff L.V., K.E. Gregory, F.J. Schwulst and R.M. Koch, 1974b. Effects of heterosis on maternal performance and milk production in Hereford, Angus and Shorthorn cattle. Journal of Animal Science, 38:728-745.

Cundiff L.V., K.E. Gregory and R.M. Koch, 1974a. Effects of heterosis on reproduction in Hereford, Angus and Shorthorn cattle. Journal of Animal Science, 38:711-727.

Cundiff, L. V. and K. E. Gregory, 1999. What is systematic crossbreeding?. Proceeding National Cattlemen's Beef Association, Cattleman's College, Charlotte, NC, February.

Dickerson G.E., 1973. Inbreeding and heterosis in animals. In Proceedings of the Animal Breeding and Genetics Symposium in honour of Dr Jay L Lush. Champaign, Illinois, America Society of Animal Science: 54-77.

Fimland E.A., 1983. Methods of estimating the effects of heterosis. Zeits Tierz Züchtungsbiol, 100: 3-8.

Fordyce G., I.D. Loxton, R.G. Holroyd and R.J. Mayer, 1993. The performance of Brahman-Shorthorn and Sahiwal-Shorthorn cattle in the dry tropics of northern Queensland 4. Postweaning growth and carcass traits. Australian Journal of Experimental Agriculture, 35: 531-539.
Gregory K.E. and L.V. Cundiff, 1980. Crossbreeding in beef cattle: evaluation of systems. Journal of Animal Science, 51: 1224-1234.

Gregory K.E., L.A. Swiger, L.J. Sumption, R.M. Koch, J.E. Ingalls, W.W. Rowden and J.A. Rothlisberger, 1966b. Heterosis effects on growth rate and feed efficiency of beef steers. Journal of Animal Science, 25: 299-310.

Gregory K.E., L.A. Swiger, R.M. Koch, L.J. Sumption, J.E. lngalls, W.W. Rowden and J.A. Rothlisberger, 1966a. Heterosis effects on growth rate of beef heifers. Journal of Animal Science, 25: 290-298.

Gregory K.E., L.A. Swiger, R.M. Koch, L.J. Sumption, W.W. Rowden and J.E. Ingails, 1965. Heterosis in preweaning traits of beef cattle. Journal of Animal Science, 24: 21-28.

Gregory K.E., L.V. Cundiff and R.M. Koch, 1991. Breed effects and heterosis in advanced generations of composite populations for growth traits in both sexes of beef cattle. Journal of Animal Science, 69: 3202-3212.

Koch R.M., G.E. Dickerson, L.V. Cundiff and K.E. Gregory, 1985. Heterosis retained in advanced generations of crosses among Angus and Hereford cattle. Journal of Animal Science, 60: 1117-1132.

Lasley J.F., 1978. Genetics of livestock improvement. Prentice-Hall Inc, Englewood Cliffs, N.J.

Lauren N. Schiermiester, 2014. Estimation of breedspecific heterosis effects for birth, weaning and yearling weight in cattle. Theses and dissertations in animal science. Paper 94. http://digitalcommons.unl.edu/animalscidis s/94.

Long C.R. and K.E. Gregory, 1974. Heterosis and breed effects in preweaning traits of Angus, Hereford and reciprocal cross calves. Journal of Animal Science, 39:11-17.

Long C.R. and K.E. Gregory, 1975. Heterosis and management effects in postweaning growth of Angus, Hereford and reciprocal cross cattle. Journal of Animal Science, 41: 1563-1571.

Osorio-Arce M. M. and J. C. Segura-Correa, 2010. Estimates of breed direct, maternal and heterosis effects for weaning and yearling weights of beef cattle in the humid tropics of Mexico. Tropical and Subtropical Agroecosystems, 12: 463- 469.

Preston T.R. and M.B, Willis, 1970. Intensive beef production. Oxford, New York, Pergamon Press, $544 \mathrm{p}$.

Sacker G. D., J. C .M. Trail and I. L. Fisher, 1971. Crossbreeding beef cattle in western Uganda. 6. A note on hybrid vigor in Red Poll-Boran crosses. Journal of Animal Production, 13:181-184.

SAS/STAT User's Guide Statistics, 2001. SAS Institute Inc, Cary, NC.

Trail J.C.M. and K.E. Gregory, 1981. Sahiwal cattle: an evaluation of their potential contribution to milk and 
beef production in Africa. ILCA Monogr No 3, Int Livest Ctr Africa, Addis Ababa, Ethiopia.

Trail J.C.M., K.E. Gregory, H.J.S. Marples and J. Kakonge, 1982. Heterosis, additive maternal and additive direct effects of the Red Poll and Boran breeds of cattle. Journal of Animal Science, 54: 517-523.
Williams J. L., I. Aguilar, R. Rekaya, and J. K. Bertrand, 2014. Estimation of breed and heterosis effects for growth and carcass traits in cattle using published crossbreeding studies. Journal of Animal Science, 88:460-466.

\section{تأثثرات قوة الهجين والأثر الوراثى التجمعى على وزن الجسم عند تدريج ماثية الأككول البوروندية مع ماثية الساهيوا}

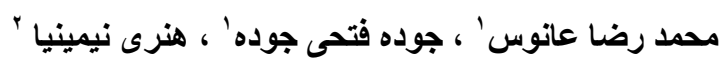

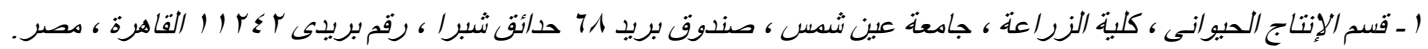

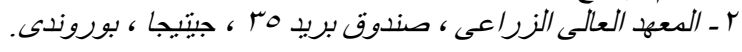

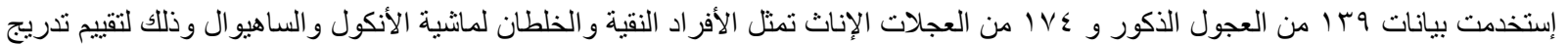

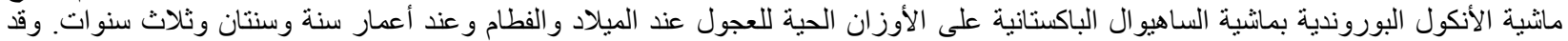

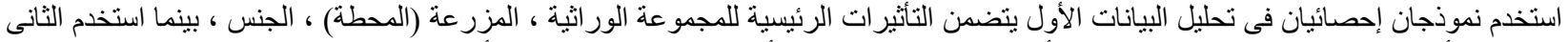

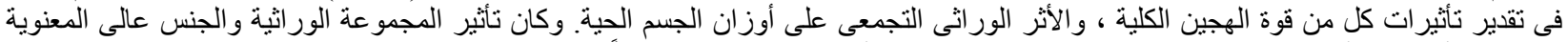

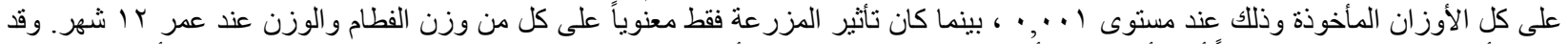

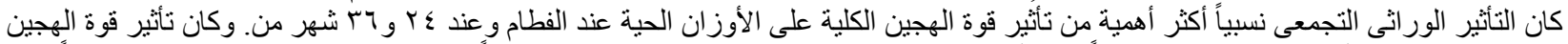

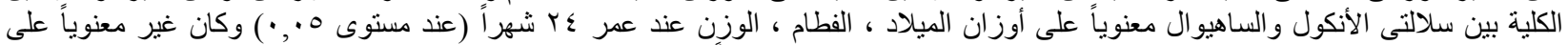

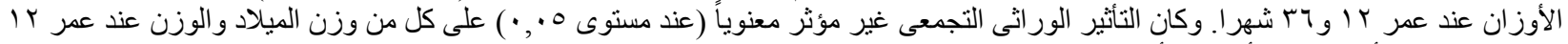
شهر على عكس تأثيره على الأوزان الأخرى. 